\title{
In silico and in vitro Studies on Lyngbya majuscula using against Lung Cancer Cell Line (A549)
}

\author{
Sangeetha Muniaraj ${ }^{1}$, Vijayakumar Subramanian $^{2 *}$, Prabhu Srinivasan $^{2}$, Manogar Palani $^{2}$
}

\section{Sangeetha Muniaraj', Vijayakumar Subrama- nian ${ }^{2 *}$, Prabhu Srinivasan ${ }^{2}$, Manogar Palani ${ }^{2}$}

\section{'Department of Microbiology Kamaraj College Tuticorin-628003, Tamil Nadu, INDIA. \\ $P G$ and Research Department of Botany and Microbiology, A.V.V.M.Sri Pushpam College, Poondi, Thanjavur-613503, Tamil Nadu, INDIA. \\ Correspondence \\ Dr. S Vijayakumar \\ Assistant Professor,}

Botany and Microbiology, A.V.V.M Sri Pushpam College (Auto.), Poondi, Thanjavur-613503, Tamil Nadu, INDIA.

E-mail: svijaya_kumar2579@rediff.com

History

- Submission Date: 03-09-2017;

- Review completed: 20-11-2017;

- Accepted Date: 05-03-2018

DOI : 10.5530/pj.2018.3.69

Article Available online

http://www.phcogj.com/v10/i3

\section{Copyright}

(c) 2018 Phcog.Net. This is an openaccess article distributed under the terms of the Creative Commons Attribution 4.0 International license.

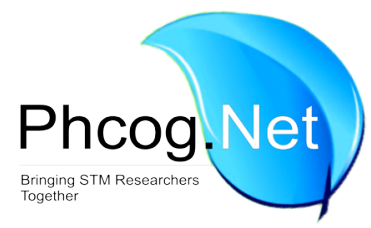

\begin{abstract}
Objective: To predict an anticancer drug from the members of cyanobacteria, in silico molecular docking was carried out between the cyanobacterial bioactive compounds and lung cancer causing receptor. The highest docking score was produced by Lyngbyastatin (Lyngbya majuscula). In the present study anticancer potential of L. majuscula was evaluated on human lung cancer cell line (A549) using its methanolic extract. Methods: Molecular docking was carried out between the Epidermal Growth Factor Receptor tyrosine kinase and cyanobacterial compounds. Based on the docking results, Lyngbyastatin was found to be the most effective compound. As this compound is present in the L. majuscula, the cytotoxicity of this organism was assessed by standard cell viability assays like MTT method. Algal methanolic extract treated with A 549 cell line morphology was studied by DAPI staining. DNA fragmentation assay was also conducted to study the presence of DNA laddering. Results: Totally 75 bioactive compounds were docked with Epidermal Growth Factor Receptor tyrosine kinase . Of them, 12 compounds were selected based on the docking score. Among the 12 bioactive compounds, Lyngbyastatin found to be most effective compound. L. majuscula showed potential anticancer activity against A549 cell line with $\mathrm{IC}_{50}$ value of $14.82 \pm 0.62 \mu \mathrm{g} / \mathrm{ml}$ in MTT method. Most of the treated cells lost their characteristic stretched appearance with shrinkage of nucleus. DNA profile revealed the presence of sheared DNA in treated ones but no fragmentation was observed. Conclusion: The results indicated potent anticancer of algal methanolic extract on A549 cell line, which may be good candidates for further investigation to isolate bioactive anticancer compounds.
\end{abstract}

Key words: Lyngbyastatin, Molecular docking, Cytotoxic, MTT assay DAPI staining, Lyngbya majuscula.

\section{INTRODUCTION}

Cyanobacteria are a phylum of bacteria that obtain their energy through photosynthesis. The name "Cyanobacteria" comes from the color of the bacteria. Cyanobacteria are a major and phylogenetically coherent group of G-negative prokaryotes possessing the unifying property of performing oxygenic plantlike photosynthesis with autotrophy as their dominant mode of nutrition. ${ }^{1}$ During the last two decades, cyanobacterial secondary metabolites have attracted the attention of researchers mainly due to two reasons; (i) acute toxicity of toxins produced by several bloom forming cyanobacteria in freshwater system and their harmful effect on animals and human health, and (ii) potential therapeutic use of several secondary metabolites. ${ }^{2,3,4}$ The secondary metabolites from cyanobacteria include a range of compounds showing animal toxicity and antibacterial, anticoagulant, antifungal, antiinflammatory, antimalarial, antiprotozoal, antituberculosis, antiviral, antitumor and cytotoxic activities. ${ }^{5,6}$

Cancer is medically known as a malignant neoplasm which is a broad group of diseases involving unregulated cell growth. In this disease cells divide and grow uncontrollably forming malignant tumors, and invade nearby parts of the body. The cancer spreads to more distant parts of the body through the lymphatic system or bloodstream. There are over 200 different known cancers that affect humans. ${ }^{7}$ Among them, brain, ovarian, prostate, lung, breast, gastric, thyroid, blood, skin and cervical cancers are more common.

Malignant brain cancer is one of the most challenging health issues for both children and adults. It is the second leading cause of cancer-related death in children and has significant morbidity and mortality in adults. ${ }^{8-13}$ According to the World Health Organization (WHO) classification (smw-1), glioblastomas (WHO grade IV) and anaplastic gliomas (astrocytomas, oligoastrocytomas, and oligodendrogliomas) (WHO grade III) are collectively referred to as malignant gliomas. Glioblastoma, the most common and most devastating glial tumor, is associated with extremely poor prognosis and high likelihood of relapse. It accounts for more than $50 \%$ of primary brain tumors. Despite significant advances in diagnostic techniques, the classical therapeutic agents are largely palliative and remain unsuccessful in providing long-term survival for patients with lung cancer. The
Cite this article: Sangeetha M, Vijayakumar S, Prabhu S, Manogar P. In silico and in vitro Studies on Lyngbya majuscula using against Lung Cancer Cell Line (A549). Pharmacog J. 2018;10(3):42128. 
conventional therapiesused todayremainsimilartothoseusedhalfacentury ago. ${ }^{14,15,16,17,18,19}$ Thus, thereisanurgentneed for novelanticancercompounds that are non-toxic, efficacious, and able to significantly improve overall treatment in patients with malignant brain tumors. In the present study, to evaluate the anti proliferative potential of methanolic extracts of the cyanobacteria on A549 cells by standard anti-proliferative assays.

\section{MATERIALS AND METHODS}

\section{Computational methods with Glide Version 6.3}

All computational studies were carried out using Glide version 6.3, installed in a single machine running on Intel Core i7 Duo processor with 1GB RAM and 275 GB hard disk with Black Dell inspiron version 7.0 as the operating system.

\section{Preparation of protein target structure}

The X-ray crystal structure of 1M17, in complex with inhibitor Epidermal Growth Factor Receptor tyrosine kinase is obtained from the Protein Data Bank (RCSB). ${ }^{20}$ Figure 1. After selection, Protein preparation wizard of Schrodinger suite has been used to prepare protein. All water molecules were removed, HET numbers are removed, missing side chains were added, hydrogen atoms are added to the proteins and all atom force field (OPSL-2001) charges and atom types were assigned. Preparation and refinement were done running ProteinPrep job on the structure in a standard procedure. Optimize and Minimized the protein were performed until the average root mean square deviation of nonhydrogen atoms reached $0.3 \AA$.

\section{Identification and Validation of binding site (Sit Map)}

The SiteMap were used to locate the ligand binding sites over the protein molecule. The Sit Map is help for the ligand interacted with amino acid residues from protein molecule. ${ }^{21}$

\section{Ligand Preparation}

These twelve natural compounds selected from Cyanobacteria these ligands are using our molecular docking studies. Those twelve compounds were sketched from Schrödinger Suit (Maestro 10.5 version) Figure 2. The compounds were prepared with the help of LigPrep (2.3) module, ${ }^{22}$ the drawn ligands were geometry optimized by using the optimized potentials for liquid simulations-2005 (OPLS-2005) force field with the steepest descent followed by truncated newton Conjugate gradient protocol. Partial atomic charges were computed using the OPLS-2005 force field. The LigPrep is a utility in Schrodinger software suite that combines tools for generating 3D structures from 1D (Smiles) and $2 \mathrm{D}(\mathrm{SDF})$ representation, searching for tautomers and steric isomers and geometry minimization of ligands.

\section{Cyanobacterial culture}

Lyngbya majuscula, a thermophilic cyanobacterium was obtained from the culture collection of AVVM Sri Pushpam College of Algal technology (AVVMSPCAT 25) Thanjavur. Biomass was obtained by growing algal cultures in $20 \mathrm{~L}$ of water and $0.25 \mathrm{~g} / \mathrm{L}$ of NPK fertilizer was added with a facility to pump the culture with aeration pump. The algae was grown for 20 days and harvested.

\section{Preparation of Cyanobacterial extract}

$0.5 \mathrm{~g}$ of dried cyanobacterial material was extracted in $20 \mathrm{ml}$ of methanol kept in an orbital shaker for overnight as described by Bortner, et al., 1995. ${ }^{23}$ The obtained extracts were filtered with Whatman no.1 filter paper and the filtrate was collected. The solvents were removed under reduced pressure at $50^{\circ} \mathrm{C}$ to yield a concentrated extract (15\%).

\section{Cell Line and Culture}

Human lung cancer A549 cell lines were obtained from National center for cell sciences Pune (NCCS). The cells were maintained in RPMI-1640 supplemented with $10 \% \mathrm{FBS}$, penicillin $(100 \mathrm{U} / \mathrm{ml})$, and streptomycin $(100 \mu \mathrm{g} / \mathrm{ml})$ in a humidified atmosphere of $50 \mu \mathrm{g} / \mathrm{ml} \mathrm{CO} 2$ at $37^{\circ} \mathrm{C}$.

\section{Reagents}

RPMI-1640 was purchased from GIBCO/BRL Invitrogen (Caithershurg, MD). Fetal bovine serum (FBS) was purchased from Gibco laboratories Trypsin, methylthiazolyl diphenyl- tetrazolium bromide (MTT), and dimethyl sulfoxide (DMSO) were purchased from (Sisco research laboratory chemicals Mumbai). All of other chemicals and reagents were obtained from Sigma Aldrich Mumbai.

\section{Cell proliferation Assay by MTT Method}

The Cytotoxicity of samples of A549 cells was determined by the MTT assay. ${ }^{24}$ Cells $(1 \times 105 /$ well $)$ were plated in $100 \mu \mathrm{l}$ of medium/well in 96-well plates (Hi media). After $48 \mathrm{~h}$ incubation the cell reaches the confluence then, cells were incubated in the presence of various concentrations of the samples in a $0.1 \%$ DMSO for $48 \mathrm{~h}$ at $37^{\circ} \mathrm{C}$. After removal of the sample solution and washing with phosphate-buffered saline $(\mathrm{pH} 7.4), 20 \mu \mathrm{l} /$ well $(5 \mathrm{mg} / \mathrm{ml})$ of $0.5 \%$ 3-(4, 5-dimethyl-2-thiazolyl)-2, 5-diphenyl--tetrazolium bromide cells (MTT) phosphate buffered saline solution was added. After $4 \mathrm{~h}$ of incubation, $0.04 \mathrm{M} \mathrm{HCl} /$ isopropanol were added. Viable cells were determined by the absorbance at $570 \mathrm{~nm}$ with reference at $655 \mathrm{~nm}$. Measurements were performed in 3 times, and the concentration required for a $50 \%$ inhibition of viability (IC50) was determined graphically. The absorbance at $570 \mathrm{~nm}$ was measured with a microplate reader (Bio-Rad, Richmond, CA), using wells without sample containing cells as blanks. All experiments were performed in triplicate. The effect of the samples on the proliferation of human Lung cancer cells was expressed as the $\%$ cell viability, using the following formula: $\%$ cell viability $=$ A570 of treated cells / A570 of control cells $\times 100 \%$.

\section{Data analysis}

The IC50 values (concentration at which $50 \%$ of the cells were dead) are reported as mean \pm standard deviation of three independent experiments. The IC50 values against the Lung Cancer Cell Line (A549) were calculated for the solvent extracts inhibiting at least 50\% inhibition when tested at a concentration. One-way analysis of variance (ANOVA) and Student t-tests were used to compare data using Statistical version 5.0 software at a $95 \%$ confidence limit.

\section{DNA Fragmentation Analysis}

A semiquantitative method for measuring apoptosis was described Bortner et al. ${ }^{23}$ Fragmentation of chromatin to units of single or multiple nucleosomes that form the nucleosomal DNA ladder in agarose gel is an established hallmark of programmed cell death or apoptosis. Briefly, the cells were cultured in $100 \mathrm{~mm}$ dishes, treated with sardine oil for $48 \mathrm{~h}$. Following this treatment, the cells were washed with $\mathrm{PBS}(\mathrm{pH} 7.5)$, harvested and pelleted by centrifugation $(12000 \mathrm{rpm})$ at $4{ }^{\circ} \mathrm{C}$. The pellet was incubated with DNA lysis buffer [10 nMTris pH (7.5), $400 \mathrm{mM} \mathrm{NaCl}$, $1 \mathrm{mM}$ EDTA and $1 \%$ Triton X-100] for $30 \mathrm{~min}$ on ice and then centrifuged at $12000 \mathrm{rpm}$. The supernatant that was obtained was incubated overnight with RNase $(0.2 \mathrm{mg} / \mathrm{ml})$ at room temperature and then with proteinase $\mathrm{K}(0.1 \mathrm{mg} / \mathrm{ml})$ for $2 \mathrm{~h}$ at $37^{\circ} \mathrm{C}$. DNA was extracted using Phenol: choloroform: isoamylalcohol $(25: 24: 1)$ mixture and precipitated with $0.1 \mathrm{M}$ of sodium acetate and 2 volume of absolute ethanol. Equal amount of DNA samples $(20 \mu \mathrm{g})$ were electrophoresed on a $1.5 \%$ agarose gel in Tris-borate EDTA buffer and visualized by ethidium bromide staining. 


\section{DAPI Staining}

DAPI staining was performed as described by Mossman. ${ }^{24}$ Briefly, the cells were seeded onto glass slides and treated with Cyanobacterial extract for $24 \mathrm{~h}$. Untreated and treated cells were rinsed with phosphate buffered saline (PBS), fixed with ice-cold 10\% trichloroacetic acid, and further washed with cold 70, 80, 90\% and absolute ethanol. The cells were permeabilized with Triton-X (10\%v/v) and stained with $1 \mu \mathrm{g} / \mathrm{ml}$ 4'-6-diamidino-2-phenylindole (DAPI) for $3 \mathrm{~min}$. To reduce the background, the stained cells was washed with PBS, cover-slipped with $90 \%$ glycerol and observed under an Image Express Micro.

\section{Estimation of Lactate dehydrogenase (EC 1.1.127)}

The enzyme is assayed based on the method King. ${ }^{25} 1.0 \mathrm{ml}$ buffer substrate and $0.1 \mathrm{ml}$ sample added into each of two tubes. Added $0.2 \mathrm{ml}$ water to the blank. Then to the test added $0.2 \mathrm{ml}$ of NAD. Mixed and incubated at $37^{\circ} \mathrm{C}$ for $15 \mathrm{~min}$. Exactly after $15 \mathrm{~min}, 1.0 \mathrm{ml}$ of Dinitrophenyl hydrazine was added to each (test and control). Left for further $15 \mathrm{~min}$, then added $10 \mathrm{ml}$ of $0.4 \mathrm{~N}$ Sodium hydroxide and the color developed was read immediately at $440 \mathrm{~nm}$. A standard curve with Sodium pyruvate solution was taken. The enzyme activity was expressed as units/mg protein in tissues.

\section{Determination of glutathione s-transferase activity (EC 2.5.1.18)}

Inhibition of the activities of cytosolic GSTs by the cyanobacterial extract was assessed as described previously by Habig et al with slight modifications. GST mediated conjugation of 1-chloro-2, 4-Dinitrobenzene (CDNB) toglutathione (GSH) was measured using multiplate reader, 425-106 at the wavelength of $340 \mathrm{~nm}$ for $5 \mathrm{~min}$. Incubation mixtures $(300 \mu \mathrm{L})$ contained $0.1 \mathrm{M}$ potassium phosphate buffer $\mathrm{pH} 6.5,30 \mathrm{mM}$ CDNB, 30mM GSH, and GST enzymes $(0.125 \mathrm{mg} / \mathrm{mL}$ cytosolic fraction). The plant extracts were dissolved in distilled water were tested at a concentration range of $1000 \mu \mathrm{g} / \mathrm{ml}-1.93 \mu \mathrm{g} / \mathrm{ml}$. Tannic acid was used as a positive control for the in vitro study at a concentration range of $0.3-10 \mu \mathrm{g} / \mathrm{mL}$. All assays were linear functions of protein concentration and of time for at least $5 \mathrm{~min}$. The enzyme activities were expressed as percent specific activity over control.

\section{Determination of Glutathione Reductase activity (EC 1.8.1.7)}

The cells were treated with different concentration of the Cyanobacterial extract for $48 \mathrm{~h}$ incubation. After incubation the dead cells were collected and the detached cells were collected by using Trypsin EDTA solution and transferred to an eppendroff tube. The homogenate was centrifuged for $45 \mathrm{~min}$ at $14,000 \mathrm{rpm}$. The pellets were suspended in a small volume of $0.25 \mathrm{Msucrose}$ and centrifuged. The supernatants were combined with the previous centrifuge. The pooled material was adjusted to $\mathrm{pH} 5.5$ with cold $0.2 \mathrm{M}$ acetic acid and centrifuged as described above (fraction). The level of total acid-soluble SH compound (glutathione GSH) was determined with Ellman's reagent. ${ }^{26}$ The buffer was mixed with $630 \mu \mathrm{l}$ of $0.5 \mathrm{M} \mathrm{K} \mathrm{HPO}$ and $25 \mu \mathrm{l}$ of mM 5, 5'-dithiobis (2-nitrobenzoic acid) (final pH 7). The absorbance at $412 \mathrm{~nm}$ was read after $2 \mathrm{~min}$. GSH was used as a standard. The rate of oxidation of NADPH by GSH at 300 was used as a standard measure of enzymatic activity. The reaction system of $1 \mathrm{ml}$ contained: 1.0mMGSSG, $0.1 \mathrm{mM}$ NADPH, $0.5 \mathrm{mM}$ EDTA, $0.10 \mathrm{M}$ sodium phosphate buffer ( $\mathrm{pH}$ 7.6), and a suitable amount of the glutathione reductase sample to give a change in absorbance of 0.05 to $0.03 / \mathrm{min}$. The oxidation of $1 \mu \mathrm{mol}$ of $\mathrm{NADPH} / \mathrm{min}$ under these conditions is used as a unit of glutathione reductase activity. The specific activity is expressed as $\mu \mathrm{M} / \mathrm{min} / \mathrm{mg}$ protein.

\section{RESULTS}

Molecular Docking of Epidermal Growth Factor Receptor tyrosine kinase with Bioactive compounds of Cyanobacteria

The docking study was performed in lung cancer protein molecules Epidermal Growth Factor Receptor tyrosine kinase (EGFR) with cynaobacterial bioactive molecules. During the time of docking analysis, there has shown five drug gable binding sites into target Figure 3. The first site was chosen based on their site efficiency like site score and site area volume Table 1. Later, the site taken for grid generation because it has fixed target site from the protein molecule. Then, all the ligand molecules are docked with target using glide module. After termination of the research, the active molecules have got superior docking scores with binding affinities. In this research, the cyanobacterial bioactive molecule lyngbyastatin has shown better docking score with drug able binding contacts than other bioactive molecules. Docked complex examination shows the residues contacts between target and lyngbyastatin Figure 4 . In this complex, the residues Lys195, Leu192, His190, Arg131, Glu231 and Arg319 were involved to the contacts formation. Specifically, residues Lys195, Leu192 and His were involved in hydrogen bond back chain contacts. The reaming residues Arg131, Glu231 and Arg319 were involved in hydrogen bond side chain formation. Arg131 was covalently binding with ligand oxygen groups Figure $4 \mathrm{a}$, $4 \mathrm{~b}$.

The recognition and affinity of ligands towards Epidermal Growth Factor Receptor tyrosine kinase protein was interpreted from hydrogen bonding formed between the amino acid residues of docked protein-ligand complex structure. The prominent binding pockets and cavities in Epidermal Growth Factor Receptor tyrosine kinase protein were identified using Glide module

Figure 5. Glide is commercial software used for docking and to predict the binding and active sites of Epidermal Growth Factor Receptor tyrosine kinase. To estimate the effectiveness of the cyanobacterial drug, docking between Lyngbyastatin and Epidermal Growth Factor Receptor tyrosine kinase protein was conducted. In this study Lyngbyastatin showed very good response with Epidermal Growth Factor Receptor tyrosine kinase causing protein Table 2 .

Totally 75 bioactive compounds were docked with Epidermal Growth Factor Receptor tyrosine kinase protein. Of them, 12 compounds were selected and the docking scores tabulated Table 2. Out of 12 ligands, Lyngbyastatin showed a highest Glide score of -9.33678 with 6 hydrogen bonds ( $3 \mathrm{~h}$-bond side chain and $3 \mathrm{~h}$-bond back chain) formed between the ligand and amino acid residues. During docking, Lyngbyastatin showed three hydrogen bonding between the ligand molecule and the amino acid residues of the receptor showing a perfect binding Figure 5. Among the 12 bioactive compounds, Lyngbyastatin was identified as the most suitable drug for lung cancer.

Table 1: Sites scores of Epidermal Growth Factor Receptor tyrosine kinase enzyme.

\begin{tabular}{ccc}
\hline R. No. & 1M17 sites & Score \\
\hline 1. & Sitemap 1M17_site_1 & 1.058309 \\
2. & Sitemap 1M17_site_2 & 0.91186 \\
3. & Sitemap 1M17_site_3 & 0.787967 \\
4. & Sitemap 1M17_site_4 & 0.752698 \\
5. & Sitemap 1M17_site_5 & 0.744084 \\
\hline
\end{tabular}


Table 2: Docking scores of Epidermal Growth Factor Receptor tyrosine kinase with Cyanobacterial bioactive compounds.

\begin{tabular}{|c|c|c|c|c|c|}
\hline R.No. & Name of the compounds & Docking score & $\begin{array}{c}\text { Glide XP Energy (kcal/ } \\
\text { mol) }\end{array}$ & Glide XP Emodel & $\begin{array}{c}\text { MMGBSA d G bind(kcal/ } \\
\mathrm{mol})\end{array}$ \\
\hline 1. & Lyngbyastatin & -9.336 & -73.538 & -90.657 & -73.313 \\
\hline 2. & Symplocamide A & -8.638 & -62.371 & -85.919 & -76.888 \\
\hline 3. & Pompanopeptin B & -8.630 & -60.297 & -63.479 & -64.286 \\
\hline 4. & Lyngbyastatin 5 & -8.115 & -60.189 & -57.846 & -65.786 \\
\hline 5. & Lyngbyastatin 4 & -8.032 & -73.820 & -61.640 & -71.220 \\
\hline 6. & Molasamide & -7.701 & -55.218 & -78.570 & -69.145 \\
\hline 7. & Nostocylopeptide A2 & -7.010 & -52.895 & -58.124 & -64.789 \\
\hline 8. & Lyngbyastatin 7 & -7.006 & -48.631 & -52.356 & -52.115 \\
\hline 9. & Symplocamide A & -6.982 & -51.720 & -32.579 & -50.071 \\
\hline 10. & Kemopeptine A & -6.825 & -54.676 & -52.529 & -54.433 \\
\hline
\end{tabular}

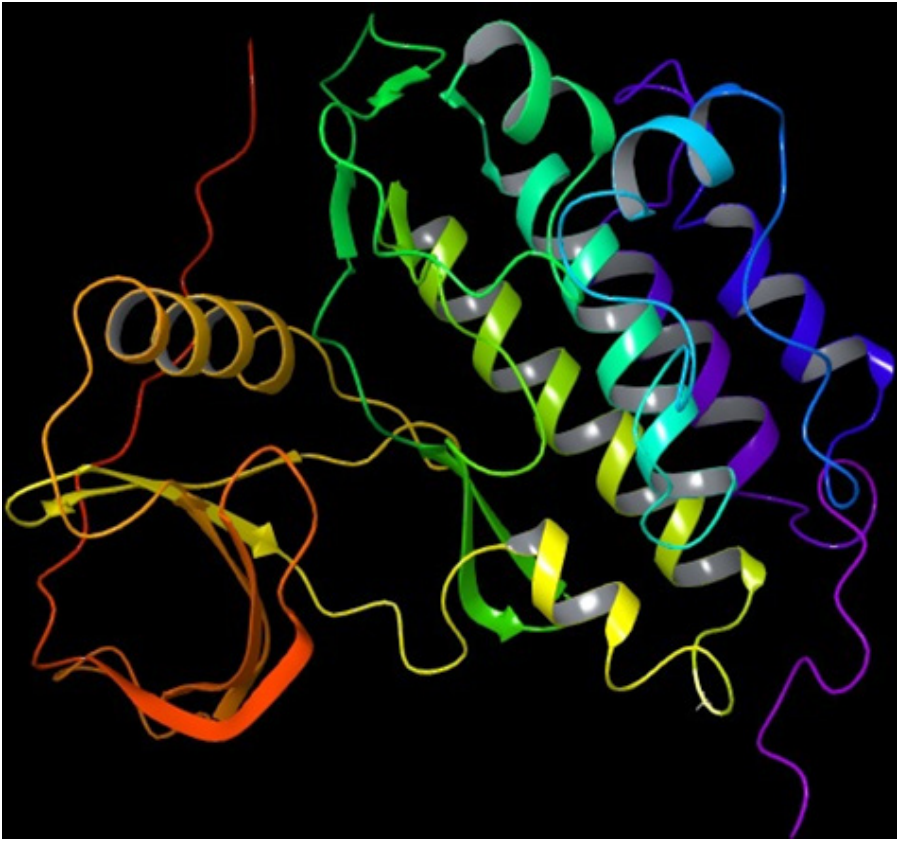

Figure 1:3D Structure of Epidermal Growth Factor Receptor tyrosine kinase.

\section{Antiproliferation assay}

Antiproliferation activity of methanolic extract of Lyngbya majuscula was determined by MTT assay. The extract showed highly potential cytotoxicity in a dose dependent manner. The cytotoxicity effect of Lyngbya majuscula extract was determined using concentration ranging from $0-1000 \mu \mathrm{g} / \mathrm{ml}$ for $48 \mathrm{~h}$. After $48 \mathrm{~h}$ exposure Lyngbya majuscula extract induced concentration dependent cytotoxicity effect in A 549 cell line with IC50 cell viability $14.82 \pm 0.62$ in MTT method Figure 6.

\section{Morphological changes of analysis}

Morphological changes of extract treated and untreated A 549 cells were demonstrated Figure 7. The most remarkable changes could be observed in extract- treated cells, including cell shrinkage and extensive detachment of the cells from the ultra surface. These changes which were the characteristics of apoptotic cell death, became visible after $24 \mathrm{~h}$ of extract treatment but were absent in control cells.

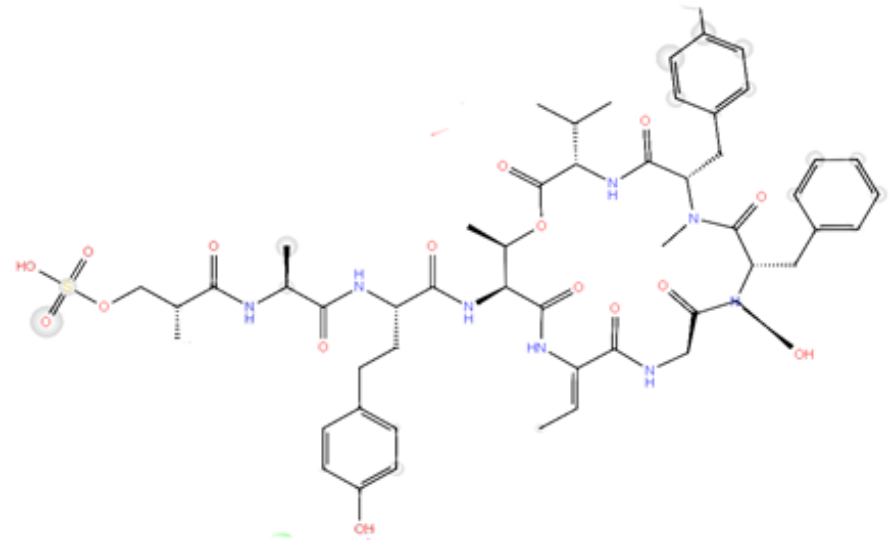

Figure 2: 2D structure of Lyngbyastatin.

\section{DNA fragmentation by DNA ladder assay}

In the present study, A 549 cell lines were treated L.majuscula extract, and the DNA was directly extracted and run on 15\% agarose gel. DNA fragmentation during apoptosis is very distinct in the gel. Figure shows that DNA laddering is pronounced for L.majuscula extract $(31.25 \mu \mathrm{g} / \mathrm{ml})$ can induce apoptosis of A549 cells (Figure 8).

\section{DAPI Staining}

Based on the antiproliferation results, DAPI staining was conducted to analys the whether Lyngbya majuscula extract induced apoptosis. Treatment of cells with Lyngbya majuscula extract at concentration of 31.25, 62.5 and $1000 \mu \mathrm{g} / \mathrm{ml}$ respectively, caused nuclear morphological changes compare to normal cells and this may be apoptosis Figure 9. Morphological changes observed in the treated cells included cell shrinkage, nuclei that were broken descript fragments and cell budding in various sizes. Concentration of Lyngbya majuscula extract appeared to cause more morphological, indicating the apoptosis occurred in a concentration dependent fashion.

\section{Cytotoxicity assay and LDH release}

Cytotoxicity assay of Lyngbya majuscula against A549 cells showed a dose dependent inhibitory effect with higher concentration being the most effective. Also there was a significant dose dependent increase in $\mathrm{LDH}$ level for $48 \mathrm{~h}$. Results were expressed as the percentage of $\mathrm{LDH}$ 


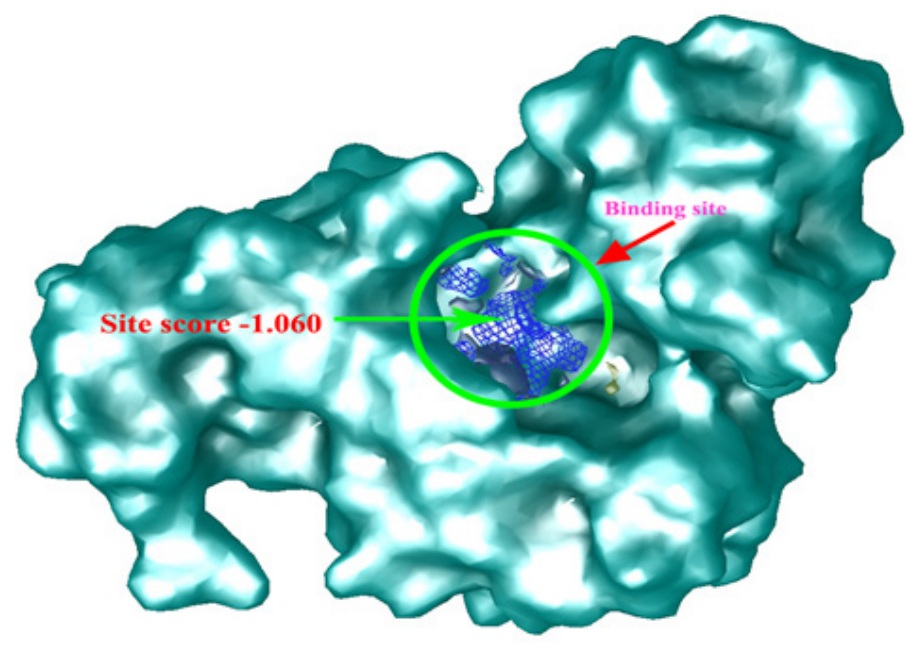

Figure 3: Active binding site of Epidermal Growth Factor Receptor tyrosine kinase with site score.
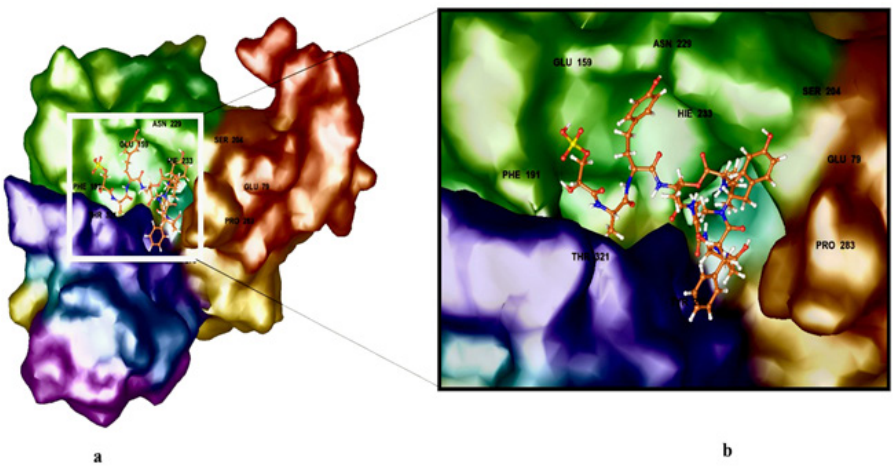

Figure 4: Molecular surface representation of binding cavity on Epidermal Growth Factor Receptor tyrosine kinase Lyngbyastatin. a). A portion of protein cavity of ligand interacted with amino acid residues. b). A Portion enlarged.

leakage was analyzed. The significant differences between control and treated of 172 cells indicated at ${ }^{*} \mathrm{P}<0.5$ and ${ }^{* *} \mathrm{P}<0.001$ Figure 10 .

\section{Effect of Glutothione Reductase (GR)}

Glutothione reductase is an important cellular antioxidant. Glutothione reductase content was higher in treated cells compare to control and treatment. GR content was gradually increased by methanolic extract. The increase in the GR activity in general, used as indication for the antitumor activity of the tested Lyngbya majuscula in A549. Figure 11.

\section{Effect of Glutothione S tranferase (GST)}

The inhibitory effect of GST activity with increasing concentration of Lyngbya majuscula extract in A549 cell line. Also the activity of GST was enhanced by incubation of tumor cells with cyanobacterial extracts. Figure 12.

\section{DISCUSSION}

According to Vijayakumar and Menakha ${ }^{27}$ marine cyanobacteria are considered to be the potential organisms as a rich source of known and novel bioactive compounds, which are effective in either killing the cancer cells or affecting the cell signalling for cancer. Among the various members of marine cyanobacteria, Lyngbya majuscula, Lyngbya sp., Lyngbya sordida, Lyngbya confervoides, Calothrix, Nostoc sp., Phormidium gracile, Symploca sp., Symploca $s p$. are highly potential organisms having antican-

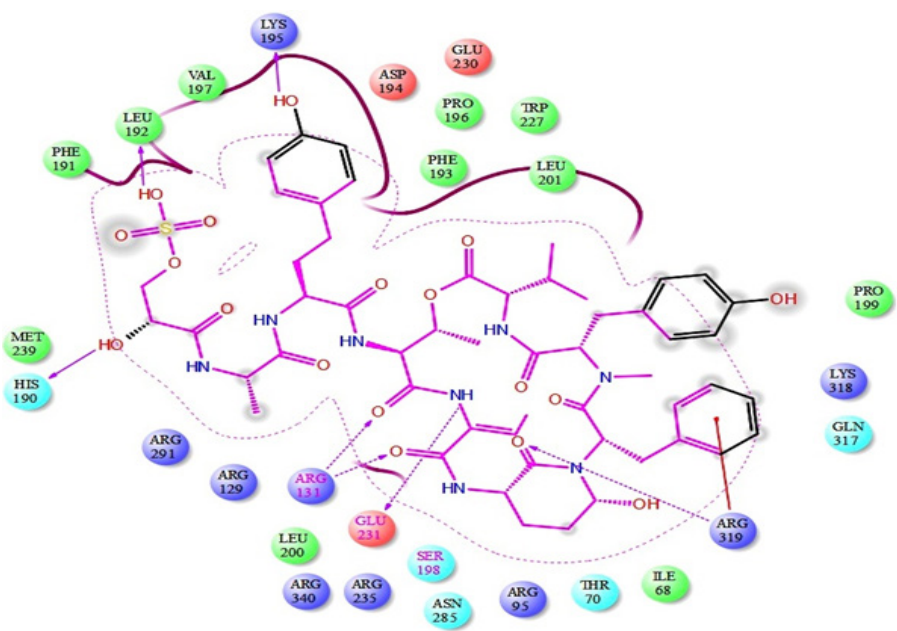

Figure 5: Ligand interaction with active site amino acid residues of Epidermal Growth Factor Receptor tyrosine kinase.

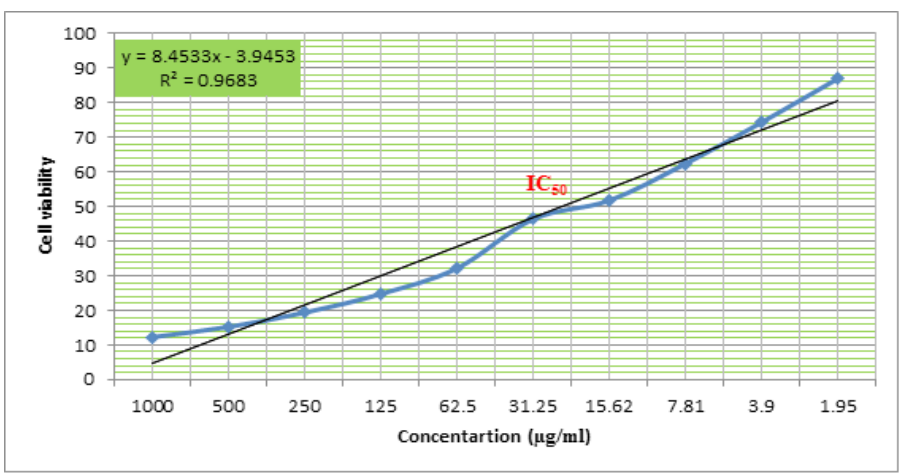

Figure 6: Graphical representation of IC 50 inhibition in MTT assay from Lyngbya majuscula.

cer drug molecules, such as antillatoxin B, apratoxin C1, arulide $\mathrm{C}$, baslyngbyaside, belamide $\mathrm{A}$, calothrixin $\mathrm{B}$, caylobolide $\mathrm{A}$, cryptophycin 6 , kemopeptinde B, hoamide D1, homodolastin, isomalgamide $\mathrm{B}$, lagunamide A1, lynbyabelin I, lynbaysolide 1,lyngbastatin, majusculamide $\mathrm{D}$, maleviamide $\mathrm{D}$, malyngamide $\mathrm{P}, 2$ epi malyngolide, nostocylopeptide, obynanamide, pitipeptolide $\mathrm{B}$, pitiprolamide, somocystinamide, symplocamide A1, symplostatin 2, tasipeptin B, tasiamide-B, tiglicamide $B$ and veraguamide $L$ were used. When these drug molecules were docked with the skin cancer causing receptor molecule HSP90, tasiamide- $B$ showed a maximum Glide score, indicating effective molecules against receptor tumor causing molecule.

Cyanobacteria have been considered as rich source of secondary metabolites with potential biotechnological applications. Lately, production of biotic compounds with commercial and medical applications has also increased. A number of important marine cyanobacterial molecules including Cryptophycin F, Cryptophycin G and calothrixin B2 A have been discovered for anticancer agent. In the presence study and induced apoptosis lung carcinoma cell line A549 at low concentration.

In the presence study MTT assay inhibition of A 549 cells was observed at different concentration of Lyngbya majuscula extract. Cell proliferation was highly significant at concentration above $50 \mu \mathrm{g} / \mathrm{ml} \quad(\mathrm{P}<0.001)$. Mukund and Sivasubramanian, ${ }^{26}$ reported most the principle component in cyanobacterial extracts are polyphenol and chlorophyll have shown anticarcinogenic activity and these have higher bioavailability. In 

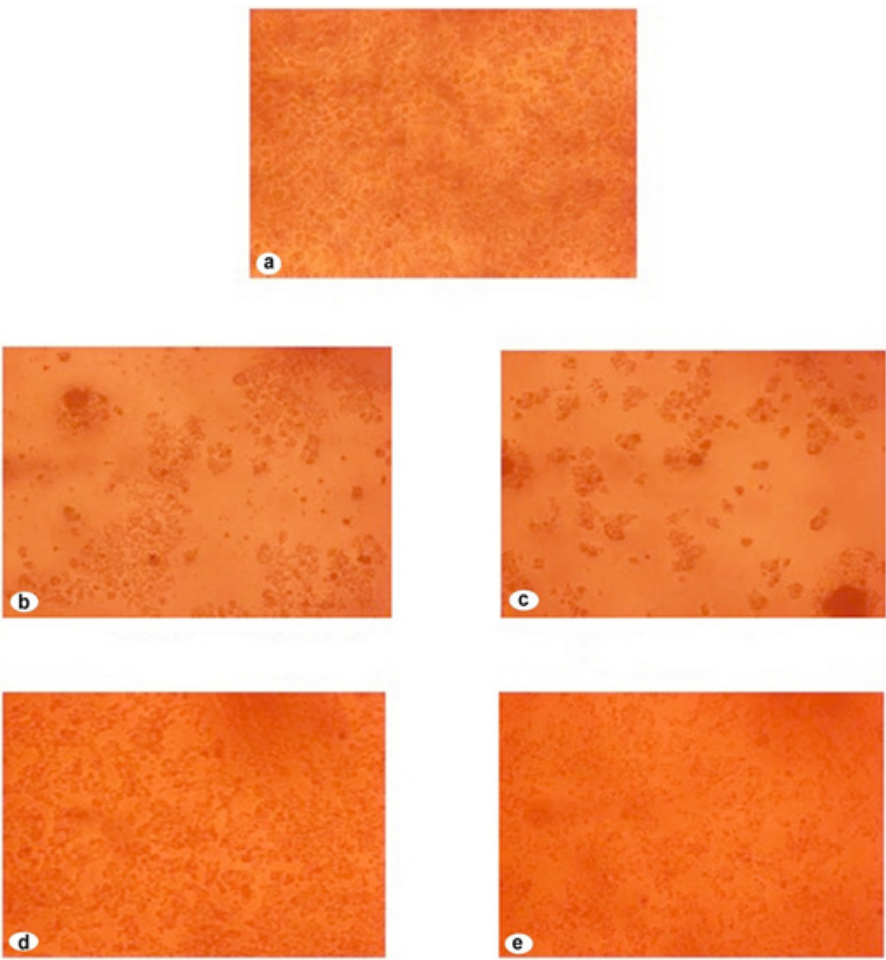

Figure 7: Cytotoxicity effect of samples on lung cancer line. The cells were treated with various concentration: (a). Normal A549 cells; (b). Treated 1000 $\mu \mathrm{g} / \mathrm{ml}$; (c). Treated $500 \mu \mathrm{g} / \mathrm{ml}$; (c). treated 62.5; (e). Treated $15.6255 \mu \mathrm{g} / \mathrm{ml}$ of Lyngbya majuscula for $24 \mathrm{hrs}$.

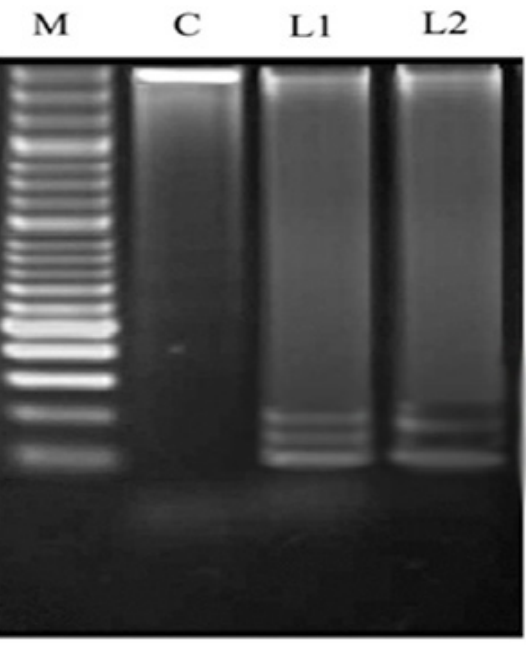

Figure 8: DNA fragmentation analysis treated on Lyngbya majuscula.

the present study, the inhibition of lung cancer cells may be due to the presence of flavonoid.

In culture medium, there is a measurement of LDH and GST content in apoptosis research that is used an indicator for cytotoxicity. ${ }^{26}$ As a result of the present study cytotoxicity also got the inducement owing to loss of membrane integrity by the extractment of cyanobacterial. It may happen owing to high presence of flavonoids. Cells release LDH because of damage in cell membrane. LDH indicates cell death either owing to necrosis or apoptosis.

Lyngbya majuscula destroy cancer cells. LDH is found as a cytosolic marker. Cyloplasmic enzymes for instance alkaline and acid phosphatase,
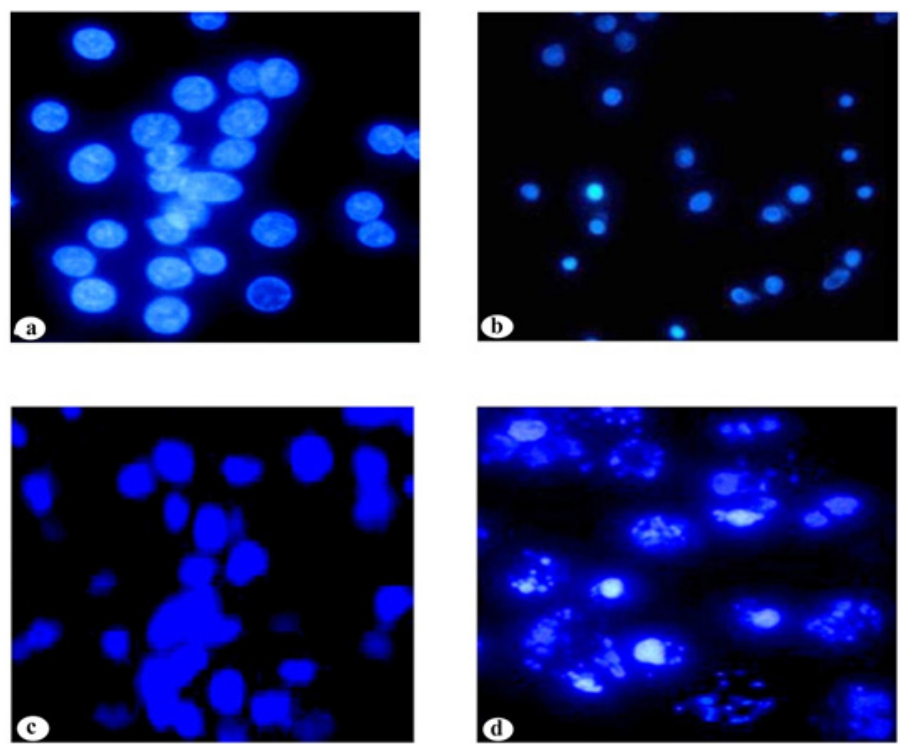

Figure 9: DAPI staining of Lyngbya majuscula; (a). Control; (b). Treated 31.25 $\mu \mathrm{g} / \mathrm{ml}$; (c). Treated $62.5 \mu \mathrm{g} / \mathrm{ml}$; (d). Treated $1000 \mu \mathrm{g} / \mathrm{ml}$.

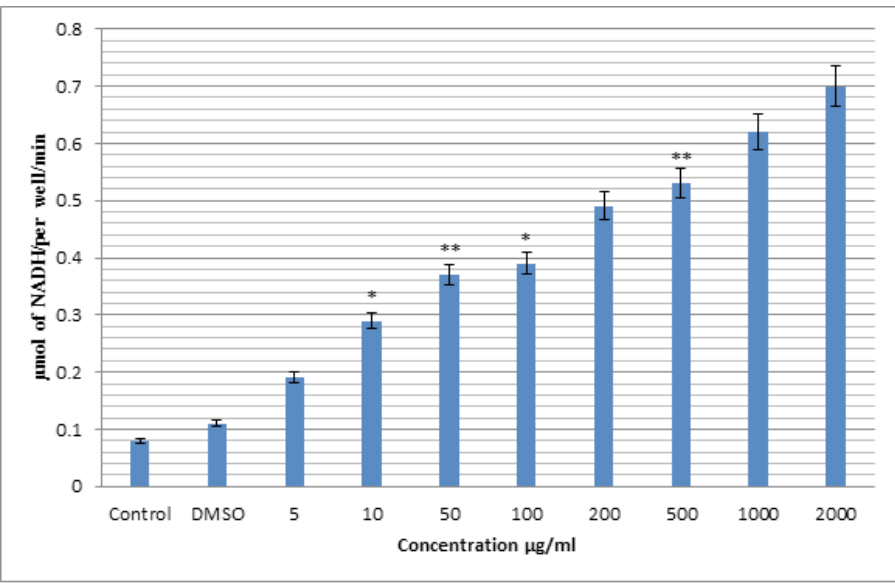

Figure 10: Lactate Dehydrogenase (LDH) activity of Lyngbya majuscula in Lung Cancer Cell lines.

glutamate - oxalacetate transminase, glutamate pyruvate transaminase and arginosuccinatelyase are released because of cell death by apoptosis. Uses of these enzymes are limited comparing with LDH because of low amount of the enzymes presented in many cells. At the same time, $\mathrm{LDH}$ is a stable cytoplasmic enzyme. This is discharged into the culture medium due to loss of membrane integrity resulting from apoptosis. Therefore, LDH activity can be used to be an indicator of cell membrane integrity and also it can be served to be a general means to assess cytotoxicity resulting from chemical compounds or environmental toxic factors. ${ }^{28} \mathrm{NAD}$ is used as cofactor by lactate dehydrogenase for regulating the interconversion of pyruvate to lactate. In the metabolism of carbohydrates, centre for delicately balanced equilibrium is formed by $\mathrm{LDH}$, the tetrameric protein which also takes part in the biosynthesis of carbohydrates. The high glycolytrerate is important for rapidly multiplying cancers. This is not only a major energy source but also providing cells with precursors for nucleotide and lipid biosynthesis. The level of LDH is elevated during cancerous conditions because of the high glycolytricrate. ${ }^{29}$ Tumor cells have an increased glucose transport. This glucose is metabolized through the anaerobic glycolytic pathway to produce lactic 


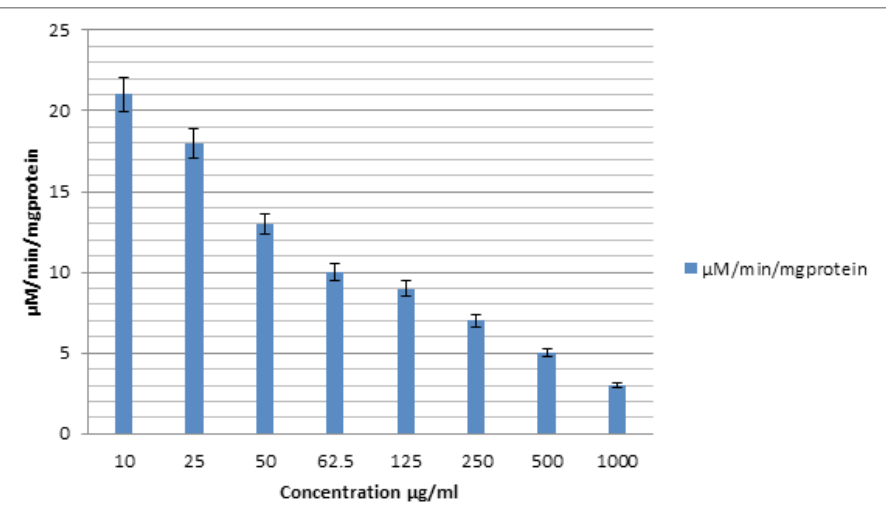

Figure 11: Gutothione reductase activity of Lyngbya majuscula in Lung Cancer cell lines.

acid. ${ }^{30}$ Malignant tumors produce a high level of lactic acid as it has high rates of glycolytic activity was observed in NAC treated cells infecting with induction in cell multiplication. ${ }^{31}$ Almost all reports suggest that cyanobacterial extract treatment has an inhibiting effect over the multiplying mass.

Gupta et $a l^{32}$ studied the relationships between antitumor activity and antioxidant role in anticancer activity. Increase in the GST activity in general used as an indication for the antitumor activity of the tested materials in both normal and tumors transplanted animals. ${ }^{33}$ Therefore, that enzyme is used as antitumor factor. Increase of cellular enzymes in the tumor cells regulates the cell oxidative stress for such as instance SOD and GST and GSH. Antioxidants which induce cancer regression and large number of tumor necrosis factor (TNF). TNF is one of the most important growth modulatory cytokines. This is produced by almost all cell types of the immune system. GST inhibitors modulate drug resistance through sensitizing tumors cells to anticancer drugs. ${ }^{26}$

Cytosolic GST plays a vital role to catalyze the nucleophilic attack of reduced glutathione (GSH). Increase in the activity of GST is an indication for the antitumor activity of the tested materials. Therefore, that enzyme is used as antitumor. Cellular enzymes regulate the cell oxidative stress for instance such as GST in the tumor cells. Up to $10 \%$ of the glucose consumption shall be directed to PPP to produce NADPH needed for this reaction when cells disclosed to high levels of oxidative stress, like red blood cells. But in the case of erythrocytes, oxidative stress in the cell will lead to cell lyses and anemia if PPP is not functional. ${ }^{34}$ Results from this study clearing show that cytotoxic activity will be induced or stimulated by Lyngbya majuscula Ag.VIA To 10 against A549 cells.

\section{ACKNOWLEDGEMENT}

The authors are grateful to the DST-SERB (SB/YS/LS-109/2014) for providing financial assistance for this project. We especially express our thanks to the management of A.V.V.M. Sri Pushpam College (Autonomous), Poondi, for providing the necessary facilities and support to carry out this work.

\section{CONFLICT OF INTEREST}

The authors declare that there is no conflict of interest.

\section{SUMMARY}

Lung cancer, also known as lung carcinoma, is a malignant lung tumor characterized by uncontrolled cell growth in tissues of the lung. This growth can spread beyond the lung by the process of metastasis into nearby tissue or other parts of the body. Most of the cancers that start in

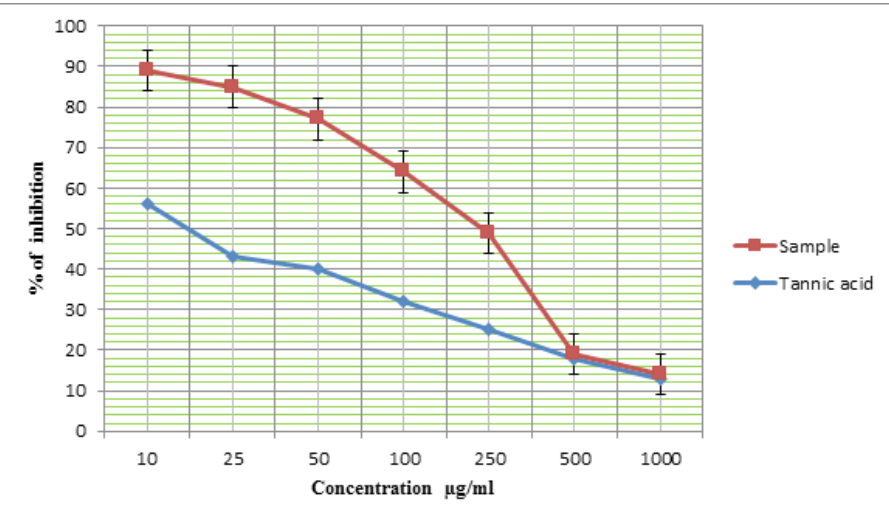

Figure 12: Glutathione S- transferase activity of Lyngbya majuscula in Lung Cancer cell lines.

the lung, known as primary lung cancers, are carcinomas. The two main types are small-cell lung carcinoma and non-small-cell lung carcinoma. The most common symptoms are coughing, weight loss, shortness of breath, and chest pains. The eighty five percentage of cases are affected by lung cancer due to long-term utilization of tobacco smoking.

\section{REFERENCES}

1. Castenholz RW, Waterbury JB. Cyanobacteria' in Bergery's manual of systemaric bacteriology. 1989;1(3):171-9.

2. Namikoshi M, Rinehart KL. Bioactive compounds produced by cyanobacteria. $J$ Ind Microbiol Biotechnol. 1996;17(5-6):373-84

3. Burja AM, Banaigs B, Abou-Mansour E, Burgess JG, Wright PC. Marine cyanobacteria- a prolific source of natural products. Tetrah let. 2001;57(46):9347- 77.

4. Dittmann E, Wiegand C. Cyanobacterial toxins-occurrence, biosynthesis and impact on human affairs. Mol Nutr Food Res. 2006;50(1):7-17.

5. Rinehart KL, Shaw PD, Shield LS, Gloer JB, Harbour GC, Koker MES, et al. Marine natural products as sources of antiviral, antimicrobial, and antineoplastic agents. Pure Appl Chem. 1981;53(4):795-871.

6. Tziveleka LA, Vagias C, Roussi V. Natural products with anti-HIV activity of marine organisms. Curr Top Med Chem. 2003;3(13):1512-35.

7. Anonymous. How many different types of cancer are there? Cancer Res UK [CancerHelp UK]. 2012

8. Hassaneen W, Levine NB, Suki D, Salaskar AL, de Moura Lima A, McCutcheon IE, et al. Multiple craniotomies in the management of Multifocal and multicentric glioblastoma. Clinical article. J Neurosurg. 2011;114(3):576-84.

9. Ahsan $\mathrm{H}$, Neugut Al, Bruce JN. Trends in incidence of primary malignant brain tumors in USA, 1981-1990. Int J Mol Epidemiol Genet. 1995;24(6):1078-85.

10. Jukich PJ, Mc Carthy BJ, Surawicz TS, Freels S, Davis FG. Trends in incidence of primary brain tumors in the United States 1985-1994; Neuro-Oncol. $2001 ;(3) 141-51$.

11. Kohler BA, Ward E, Mc Carthy BJ, Schymura MJ, Ries LA, Eheman C, et al. Annual report to the nation on the status of cancer, 1975-2007. Featuring tumors of the brain and other nervous system. J Nati Cancer Inst. 2011;103(9):714-36.

12. Smith $M$, Freidlin $B$, Ries $L A$, Simon $R$. Trends in reported incidence of primary malignant brain tumors in children in the United States. J Nati Cancer Inst. 1998;90(17)1269-77.

13. Zada G, Bond AE, Wang YP, Giannotta SL, Deapen D. Incidence trends in the anatomic location of primary malignant brain tumors in the United States: 1992 2006. World Neurosurg. 2012;77(3):518-24.

14. Henriksson R, Asklund T, Poulsen HS. Impact of therapy on quality of life, neurocognitive function and their correlates in glioblastoma multiforme: A review. J Neuro-oncol. 2011; 104(3):639-46.

15. Amelio D, Lorentini S, Schwarz M, Amichetti M. Intensity-modulated radiation therapy in newly diagnosed glioblastoma: A systematic review on clinical and technical issues. Radiother and Oncol. 2010;97(3):361-9.

16. Caldwell WL, Aristizabal SA. Treatment of glioblastoma multiforme A review Acta Radiologica: Therap Physic Biol. 1975;14(6):505-12.

17. Jubelirer SJ. A review of the treatment and survival rates of 138 patients with glioblastoma multiforme. Ournal - West Virginia State Medical Association. 1996;92(4):186-90.

18. Rock K, Mc-Ardle O, Forde P, Dunne M, Fitzpatrick D, O'Neill B, et al. A clinica review of treatment outcomes in glioblastoma multiforme - the validation in a non-trial population of the results of a randomized Phase III clinical trial: Has a more radical approach improved survival? Brit J Radiol. 2012;85(1017):e729-33. 
19. Slatkin DN, Glioblastoma treatment. Science. 1994;265 (5179):1644-5.

20. http://www.rcsb.org

21. SiteMap, Schrödinger, LLC, New York, NY, 2017.

22. Ligprep. Version 2.3, Schrodinger, LLC, 2009 NewYork.

23. Bortner CD, Oldenburg NBE, Cidlowski JA. The role of DNA fragmentation in apoptosis. Trend Cell Biolo. 1995;5(1):21-6.

24. Mossman T. Rapid colorimetric assay for cellular growth and survival: application to proliferation and cytotoxicity assays. J Immunol Meth. 1983;65(1-2):55-63.

25. King J. Methods for determination of enzyme activity". In Practical Clinical Enzymology. Divine Mother and Co, Ltd. London. 1965;106-15.

26. Mukund S, Sivasubramanian V. Anticancer Activity of Oscillatoria terebriformis Cyanobacteria in Human Lung Cancer Cell Line A549. Int J Appl biol pharmace Technol. 2014;5(2):34-45

27. Vijayakumar $S$, Menakha M. Tasiamide- $B$ a new cyanobacterial compound for treating skin cancer. Biomed Prev Nutri. 2014;4(3):355-8.

28. Akhtar N, Miller MJS, Haqqi TM. Effect of a Herbal-Leucine mix on the IL-1b-induced cartilage degradation and inflammatory gene expression in human chondrocytes. BMC Complemen Alter Med. 2011;11(66):1-10.

29. Li N, Tan W, Li J, Li P, Lee S, Wan Y, et al. Glucose Metabolism in Breast Cancer and Its Implication in Cancer Therapy. International Journal of Clinical Medicine. 2011;2(13):110-28

30. Legrand C, Bour JM, Jacob C, Capiaumont J, Martial A, Marc A, et al. Lactate dehydrogenase (LDH) activity of the number of dead cells in the medium of cultured eukaryotic cells as marker. J Biotechnol. 1992;25(3):231-43.

31. Sridharan S, Nalini R, Shyamala-Devi CS. In vitro Evaluation of the Anticancer Effect of N Acetyl cysteine On Oral Carcinoma Cell Line. IND J Pharmacol. $2001 ; 33(5): 343-9$

32. Gupta M, Mazumder UK, Kumar RS, Kumar TS. Antitumor activity and antioxidant role of Bauhinia racemosa against Ehrlich as cites carcinoma in Swiss albino mice. Acta Pharmacol Sin. 2004;25(8):1070-6.

33. Oude-Ophuis MB, Mulder TPJ, Peters WHM, Manni JJ. Plasma glutathioneStransferase $\mathrm{Pl}-1$ levels in patients with head and neck squamous cell carcinoma. Cancer. 1998;82 (12):2434-8.

34. Gallo G, Martino G. Red blood cell glutathione peroxidase activity in female nulligravid and pregnant rats. Reprod Biol Endocrinol. 2009;7(7):1-7.

\section{GRAPHICAL ABSTRACT}

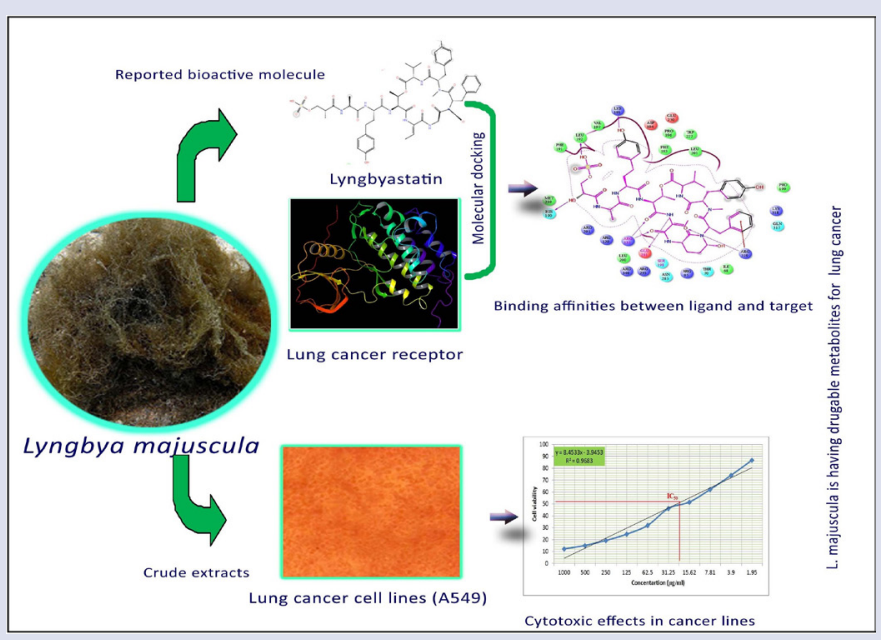

\section{SUMMARY}

- Lung cancer, also known as lung carcinoma, is a malignant lung tumor characterized by uncontrolled cell growth in tissues of the lung. This growth can spread beyond the lung by the process of metastasis into nearby tissue or other parts of the body. Most of the cancers that start in the lung, known as primary lung cancers, are carcinomas. The two main types are small-cell lung carcinoma and non-small-cell lung carcinoma. The most common symptoms are coughing, weight loss, shortness of breath, and chest pains. The eighty five percentage of cases are affected by lung cancer due to long-term utilization of tobacco smoking.

\section{ABOUT AUTHORS}

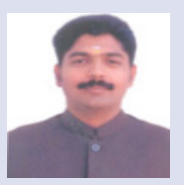

Dr. S. Vijayakumar: Has received his doctorate degree from Barathidhasan University and has more than $15 y e a r s$ of teaching experience at U.G. and P.G. levels. He has 15 years of research experience. He is workingas Assistant Professor in the Department of Botany and Microbiology, A.V.V.M. Sri Pushpam College (Autonomous), Poondi-613 503, Thanjavur district, Tamil Nadu. He has got vast experience in research especially on cyanobacteria, Medicinal plants, Environmental Microbiology and Computer Aided Drug Design (CADD). He has guided P.G. students for their projects in the field of fresh water Algae, Medicinal plants and Bioremediation. At present he is completed $11 \mathrm{Ph} . \mathrm{D}$ and guiding $7 \mathrm{Ph} . \mathrm{D}$. programme in this line. So, far he has guided $22 \mathrm{M}$. Phil., candidate for their degree and published 68 research papers in the international level journals. He has got best paper award from National Symposium on "Algae, Man and Biosphere" and International Medicinal Plants and Pharmacological Research, Columbo University, Srilanka. Recently, he got YOUNG SCIENTIST AWARD from Wasinghton University, USA. He has visited more than 8 countries which include Spain, Dubai, Sri Lanka, Singapore,etc. He also completed One UGC Minor and UGC Major Project. Right now one DST-SERB major project is ongoing in the area of Computer Aided Drug Design and Modelling.

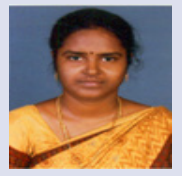

Dr. M. Sangeetha: Has received graduation and post graduation in Microbiology from Barathidasan University. Presently, She is working as Assistant Professor, Departmment of Microbiology, Kamaraj College, Thiruchendur Road Tuticorin- 628003.

Cite this article: Sangeetha M, Vijayakumar S, Prabhu S, Manogar P. In silico and in vitro Studies on Lyngbya majuscula using against Lung Cancer Cell Line (A549). Pharmacog J. 2018;10(3):421-28. 